\title{
The value of university social entrepreneurship education and its implementation model
}

\author{
Gao chao \\ Wuhan university of technology, department of student affairs, Hubei, Wuhan, 430063
}

Keywords: Entrepreneurship education; Value; Implementation mode

\begin{abstract}
College entrepreneurship education embodies the important value on meeting the demand of college students' all-round development, promoting the development of higher education and the institutions of higher learning, and promoting social progress, but there are obvious contradictions between the urgent demand of current social development to entrepreneurship education and practice and the absence of entrepreneurship education and practice development of. Reference to research experience of other countries, building the localization of social entrepreneurship education system, creating entrepreneurial culture atmosphere of society and colleges and universities, seeking government support and social force assist, and exploring the social entrepreneurship education value realization mode, can effectively solve the contradiction.
\end{abstract}

Social Entrepreneurship is social practice activities for individuals or social organizations who are driven by strong social responsibility, based on the social reality needs and a new social organization, to continuously and creatively provide products or services for the society, and to furthest pursue social benefits.It mainly focuses on the social problems government and the market system have not fully solved and the needs not fully met. Through assessing and grasping the opportunity, the entrepreneurs make full use of the innovation ability to integrate social resources, and constantly seek a balance between observing social ethical norms, and pursuing economic interests. Entrepreneurship education is rich in connotation and extension of extension of entrepreneurship education, emphasizing on education of consciousness, spirit, knowledge, ability social entrepreneurship needed and their corresponding social entrepreneurship practice ${ }^{[1]}$.The university entrepreneurship education mainly faces young students to guide them to focus on social problems, continuing to create social value by finding the opportunities among it and cultivating their social consciousness and entrepreneurship and innovation abilities.In contemporary social development, social entrepreneurship plays a more and more important role in civil society construction, economic and social development, promotion of ecological society. The colleges and universities is an important field to carry out the entrepreneurship education. In terms with domestic and foreign social entrepreneurship education development, most successful social entrepreneurship have roots in the original foundation of school education.The domestic entrepreneurship education development just now takes the first step. Inspecting colleges and universities entrepreneurship education value from aspects of promoting social progress and the education development, meeting the demand of individual growth, developing the university entrepreneurship education from aspects of drawing lessons from foreign experience, developing local school education, and creating a social atmosphere have important social practical significance.

\section{The value embodiment of university entrepreneurship education}

Value reflects the subject needs and satisfaction relationship, only the interests of the principal demand is satisfied, the object can have existence meaning and the possibility of development.In terms with college entrepreneurship education, personal and social is the main body of value, and its itself is the object of the value, the individual development demands and the satisfaction of social interests demands constitute the value foundation of existence and development of university 
entrepreneurship education. And because universities entrepreneurship education is the composition of higher education, is the extension of entrepreneurship education, its development, to a certain extent, also met demand for the development of higher education including rich connotation, the expansion of form of development and function realization, etc.

(1) The university entrepreneurship education meets the needs of college students' all-round development, and reflects the individual value.

Man's all-round development reflects the diversity, mainly including the all-round development of the people's needs, human activities and ability, people's social relations and personality. General study of the comprehensive development for college students mainly refers to the all-round development of college students' knowledge and skills, including mastery and application of comprehensive knowledge, also including comprehensive training of practical skills and potential ability; The all-round development of college students' social relations refers to the fact that in expanding social interactions, they can widely contact more people of areas or regions, and communicate with them about good information both materially and spiritually, strengthening the dependence between the individual and society, forming all kinds of social relations such as ethics, political law, ideal and cultural category, and cultivating rich modern social capital;The all-round development of college students' personality mainly reflects all-round development of the university student individual uniqueness, autonomy, initiative and creativity, making the college students in the social life practice, on the basis of fully respecting individual differences, actively exert innovation and creation ability, and cultivate good personality traits.

Colleges and universities entrepreneurship education has its distinct uniqueness compared with courses education of other disciplines, and can fully meet the demand of the all-round development of college students. First of all, the content comprehensiveness of social entrepreneurship education can promote systematicness of college students' knowledge structure. Entrepreneurship education is not only a simple cultivation of skills and entrepreneurship theory, and also must be combined with the mastery and comprehensive use of multidisciplinary professional knowledge such as natural science and social science, including social problem oriented by science and technology application and entrepreneurial process oriented by knowledge of economic, management, law, sociology and other disciplines, and promoting the construction of college students systematic knowledge structure. Secondly, the sociality and public welfare to social entrepreneurship is premise and core concept of the implementation of entrepreneurship education. By guiding students to actively concern and scientifically understand social problems, it guides them to participate in solving social problems, and to be committed to the pursuit of social benefits, which can effectively enhance the students' consciousness of civil society, social responsibility, and improve the level of political thought and citizens' moral consciousness, promoting the inheritance and development of the traditional culture, and then developing rich social relations.Thirdly, the practice and innovation of social entrepreneurship is the essence requirements of entrepreneurship to education. Depending on the innovative consciousness and ability, creatively providing products and services for the society, is the central task of social entrepreneurship. Social entrepreneurs, according to cultivated and personalized features such as interest and ambition, professional skills, personality traits, carry out the practice of social entrepreneurship, and constantly strengthen the individual characteristic in the process, realizing the value pursuit of personalization in the practice of creating social value .

(2) The university entrepreneurship education promotes the development of higher education, and reflects its collective value.

Colleges and universities entrepreneurship education bears the important function of higher education.Higher education function mainly includes training innovative talents;Conducting 
scientific research and promoting the development of science and technology;Directly meeting the demand of social reality and servicing the social development; Inheriting and innovating social culture. Along with the social change and the acceleration of transformation, the higher education function also appears detuning phenomenon, not well coordinates the relationship between the satisfaction of individual interests and the demand social interests, showing utilitarian on the value choice and pursuit and commercializing in the education practice."Ignoring the side of non-physical super utilitarian value, namely, which guides the student to set up the correct values and life ideal, shape students good character, train students' strong sense of national pride and to bear social responsibility, and inherit human culture, value, knowledge and culture, make the students become qualified citizens who are beneficial to the society and human civilization", ${ }^{[2]}$ make functional results and real efficiency sell at a discount greatly. Colleges and universities entrepreneurship education insists on combining with ideological and political education, professional knowledge skill learning, extracurricular academic science and technology innovation practice and social development actual needs, attaching importance to the cultivation of innovative talents, guiding educatees to innovate application of professional skills, serving for the society economy development and the construction of civil society, pursuing the maximization of social interests, effectively adjust detuning phenomenon of higher education, promoting the its function transformation in knowledge economy era.

Colleges and universities entrepreneurship education can realize the connotation extension of entrepreneurship education and form expansion.Business includes both create business start-ups of a organization with profitability, also nonprofit social entrepreneurship, so in terms with the category of entrepreneurship, social entrepreneurship is a positive complement to entrepreneurship, also is the realistic requirement and future trend of business development. Entrepreneurship education, in the framework of entrepreneurship education, in addition to the education training of general knowledge of entrepreneurial skills, focuses on education practice form which combines the social responsibility education, public welfare spirit fosters and innovation and entrepreneurship education, promoting the formation of the "great view of entrepreneurship", so from the perspective of the development of entrepreneurship education discipline, entrepreneurship education is rich and extension of entrepreneurship education connotation. Compared with a general sense of business start-ups, social entrepreneurship pays more attention to solve the social reality problems, meet the demand of social development, need various forms of research practices to objective cognize social problems, seek and evaluate business opportunities, as well as the practice entrepreneurial creativity. Entrepreneurship education extends the traditional entrepreneurship education form, emphasizes on public welfare activities platform relying on diversification, to realize the combination of public welfare education and business practice.

Colleges and universities entrepreneurship education is helpful to improve the core competitiveness and brand image of colleges.College entrepreneurship education guide the teachers and students to concern social problems wider and deeper, relying on the subject and professional knowledge, independently to research and development of new products, innovate service mode, in order to effectively solve the social problems. First of all, modern social development gives a very big space to the non-profit organization, our country society in the transition period also need to rely on active participation of "third sector"outside the government and the market.

Under this background, it is undoubtful that the social entrepreneurship and its education see in development opportunity, easier for colleges and universities to conduct entrepreneurship education and practice at the same time, improve the independent innovation ability of teachers and students, create creative brand of school own. Secondly, college students are full of youthful vitality and 
strong independent consciousness and self-realization desire, coupled with lower risk and higher success rate of social entrepreneurship than the general business, so it is easy to form a strong innovative entrepreneurial atmosphere on campus, enriching campus cultural connotation, improving the quality of campus culture. Thirdly, social entrepreneurship directly faces the social public, involving social issues of common public concern. With the in-depth development of entrepreneurship practice, more and more people begin to accept, recognize and welcome services items young students provide.In this way, when the entrepreneurial team or organization output social benefits and obtain economic benefits, also has realized the college's own cause marketing and enhanced brand image.

(3) The university entrepreneurship education promotes social development, and reflects its social value.

Entrepreneurship education contributes to promoting the development of social economy.Commercial operation mode is essential choice for social entrepreneurship organization to maintain its vitality, and constantly develop and create more social value. Through integration of various social resources, entrepreneurs integrate of folk working capital and idle cash of enterprises and individuals, or based on a small number put on earlier, originality and opportunities advantage to innovate operation mode, optimize the allocation of resources to move more social resources, reduce the government financial burden, and save social cost. Integration of social surplus or idle human resources is a big characteristic of social entrepreneurship. When opening up the new employment field and creating more jobs, it will make full use of its advantages in human resources, create the labor value and promote the development of economic society. Commercial operation pattern is difficulty and bottleneck of social entrepreneurship, especially for college students, which will also become the important content of entrepreneurship education.

Entrepreneurship education is helpful to promote socialist spiritual civilization construction. Public spirit embodies the socialist advanced culture and the fundamental requirement of socialist core values, and absence of public welfare culture and the lack of understanding of social entrepreneurship are important factors restricting the development of entrepreneurship in our country. Entrepreneurship education is not only popularize public welfare cultural knowledge, but also can make common civic consciousness, the concept of self-government, the legal system idea, the spirit of contract and public spirit adapted to market economy advocated,can enhance the social responsibility of educatees, and help them establish correct thought consciousness and values consciously, making social entrepreneurs consciously abide by social rule of law and moral rules.In addition, the practice of social entrepreneurship has a strong demonstration effect, which can promote social consciousness and moral level of more community members, carry forward the spirit of innovation, collective idea and public welfare concept, build good social atmosphere,and promote the socialist spiritual civilization construction.

Entrepreneurship education is helpful to promote the construction of civil society.Social entrepreneurship for the whole society, is practical process of explaining the core value of social innovation and spreading collective ideas and beliefs of social innovation;In terms of entrepreneurs individual, it is an effective way to participate in social management innovation and promote social efficient functioning.In the entrepreneurship practice, in their daily life behaviors social public can feel social development driving force and the change force from the grassroots power, see the positive response to problems of social reality of social public organizations and individuals, recognize that social development change is not always the top-down "management"mode of, also "governance"mode from the bottom to up, from individual to group, from micro to macro, deeply awaken social public of civic awareness and social participation motives. Therefore, promoted spirit 
concept and cultivated practical skills of entrepreneurship education must become the spirit source and actual power of civil society development and civic culture.

\section{The value realization of university entrepreneurship education}

Entrepreneurship education in promoting college students' all-round development, and promote the development of higher education and the institutions of higher learning, to promote social development reflects the important value.But at present our country social entrepreneurship education development lack of theory and practice, the lack of perfect social ecological system support, the value of its obvious advantage can't display.Therefore, it is only through draw lessons from foreign entrepreneurship education research and practice experience, fully research and higher education development present situation, the trend of Chinese society, college students' growth and development regularity, to explore the localization of social entrepreneurship education mode, to realize their own value.

(1) Reference to the advanced experience of foreign entrepreneurship education

Social entrepreneurship development in western countries has profound cultural roots, with long-term development, concept of social entrepreneurship"the pursuit of social benefit maximization" has been widely popular and around human mind. In the 1980s, since American Bill Drayton pioneered Entrepreneurship(Social Entrepreneurship,also translated as "Social innovation", "Social Entrepreneurship", "Social business" or "Social innovation", "Social Entrepreneurship") concept, foreign countries especially in western countries the study of social Entrepreneurship is increasingly perfect, through setting up the research agency, they constructed curriculum system, improved the practice pattern, provided social support guard, etc., and actively promoted the development of entrepreneurship education and practice. First of all, set up special research institute and teams, carry out the social entrepreneurship, social entrepreneurs and entrepreneurship practice management research to lay the theoretical basis for the development of social entrepreneurship. There are more influential institutes such as entrepreneurship research center of Stanford business school, Canada social entrepreneurship research center, entrepreneurship Kurt center of Oxford University's business school,etc.Secondly, construct social entrepreneurship education and practice course system, cultivate great human resources who not only know social entrepreneurship knowledge but has entrepreneurial management skills, and form the main force to the development of social entrepreneurship. In the United States, Canada and the UK at least 30 business school set up courses related to entrepreneurship, among which Harvard business school started to recruit the first batch of entrepreneurship Dr from September in 2004. Thirdly, expand and improve social entrepreneurship practice form and carrier, through the carrier such as the development of community service, scientific and technological poverty alleviation, education support, weak concerns, and combined with integration of production, integration, business and business operation intervene form to build the reality platform of social entrepreneurship development. Fourth, the government should provide the legal policy and funding guarantee, such as reducing entry door of social enterprises, simplifying examination and approval procedures, reducing tax breaks, and providing legal protection, etc.; Other social forces provide material and technical support, such as financial investment, science and technology incubation, qualification training, set up social support system of the development of social entrepreneurship.

(2) Construction of local universities entrepreneurship education system

Entrepreneurship education is the necessary foundation of entrepreneurship development. In the current situation where our country social entrepreneurship is badly in need of development and entrepreneurship education have a serious lack, constructing the localization of social entrepreneurship education system, promoting entrepreneurship education normalized 
development, and realizing value of social entrepreneurship education and practice are particularly important. The construction of entrepreneurship education system should adhere to the principle "public interest as the prerequisite, innovation as the core", and begin with perfecting social entrepreneurship education organization and system, making the specialized teaching staff,establishing systematic curriculum system, establishing the platform of scientific research and academic, and exploring mature practice mode. Firstly, strengthen college entrepreneurship education leadership organization construction, support and guide the student to create entrepreneurship organization, to provide the organizational guarantee for public colleges and universities entrepreneurship education, and perfect credit certification system and incentive mechanism of social entrepreneurship education to provide institutional guarantee for entrepreneurship education. ${ }^{[3]}$ Secondly, "The teacher is the" center "'decisive key figures"of the school education activity".." ${ }^{[4]}$ Stick to the combination of both inside and outside school, match of full-time and part-time job to optimize the teachers structure of social entrepreneurship; Insist on paying equal attention to the business ability and personal accomplishment, grasping study in teaching and training at the same time, to enhance the level of teachers' professional qualities. Thirdly, relying on colleges and universities to set up specialized research institutions of social entrepreneurship education, through scientific research and policy support to build scientific incentive mechanism and promote scientific research of entrepreneurship education and the practice; Establish relevant academic journals, enhance academic discussion and communication among researchers to form the traction of social entrepreneurship education and practice. Fourth, explore and gradually perfect the entrepreneurship practice mode, let more teachers and students have the opportunity to participate in business practice, improve their abilities of the opportunity identification and evaluation, innovation and creativity, team management, business process management, etc.

(3) Build college entrepreneurship education cultural atmosphere

Culture has a subtle enlightenment function and potential behavioral control function, and can make the individual balance and adjust the interests relationship between the individual, collectivity and society, can also draw hearts close, improve the aesthetic. In addition, the culture is bearing the historical tradition gene, and contains diversified thinking characteristics, and can make people's cognitive ability and level continuously upgrade. Innovative entrepreneurial culture has gradually become important component of current campus culture.Social entrepreneurship culture not only promotes entrepreneurship, and full of public spirit, besides the general function of campus culture, also effectively promotes teachers and students the awakening of public welfare spirit, citizen consciousness and national dignity.Therefore, building social entrepreneurship culture not only helps the development of social entrepreneurship education and practice, and has higher spiritual value. Entrepreneurship culture in colleges and universities, first of all, we must improve the organization system, from the school development, especially the top of the cultural construction to specific implementation of links such as teaching, management, services, business practices, team incubation, and safeguard full development of social entrepreneurship education and practice; Secondly, increase social entrepreneurship education and practice of material inputs such as capital, sites, equipment, and provide the necessary material and cultural foundation of social entrepreneurship education and practice;Thirdly, to carry out various forms of social entrepreneurship education practice activities, such as through series of lectures on education, broaden the knowledge of teachers and students;By experts, entrepreneurs, BBS, let more teachers and students appreciate entrepreneurs, share experience;Through the relevant events held social entrepreneurship, arouse the teachers and students of entrepreneurial passion. 
(4) Seek social support and assurance for colleges and universities entrepreneurship education

Social entrepreneurship is social problem in leading business entrepreneurship, and the social entrepreneurship development in our country has just started, so thorough entrepreneurship social support and guarantee system are the important premise of entrepreneurship education and practice development. The first is the social and cultural support.Although public culture has always been the important component of traditional culture in our country, but with the acceleration of social change and transformation, it has exposed crisis such as value belief and good faith, resulting in the absence of public culture to a certain extent, so the cultural soil of social entrepreneurship education and practice development is slightly poor.In the current trend of promoting the great development and prosperity of socialist culture, through perfecting cultural system and building public culture opinion atmosphere, we should popularize and promote the public welfare culture to the public, making social entrepreneurship gradually go into the public life, deeply root in the hearts of the people. The second is the government policy support.Social entrepreneurship, which derived from the vacuum between gradual abdication of government in the public affairs marketization reform and the increasing social demand, is a necessary complement to the functions of government.Government, by strengthening related policies and legislation of social entrepreneurship, provides better development environment and legal system safeguard for entrepreneurship education and practice; Through giving plays to functions of policy or information service providers, the supervisors of market environment, the coordinators of social relations and other, increases support for social entrepreneurship.The third is the financial and technical support.Insufficient funds, lack of professional skills and entrepreneurial management ability are vital problems of young students entrepreneurship. Colleges and universities need to unite government and social force, strive for more venture fund support, to provide entrepreneurship management technical support for teachers and students who plan to engage in social entrepreneurship.The fourth is the achievements transformation support. University entrepreneurship education is mainly conducted in the school, and directly coming into contact with many aspects of society, government, society enterprise and individual is very limited, which will cause that scientific and technological achievements and service mode of independent innovation can not be timely and effectively implemented.Schools should strive a more convenient way of social entrepreneurship for teachers and students, unite government and social force, provide achievements transformation services through constructing achievements platform, and provide hatching or consulting services for social entrepreneurship programs through organization such as social entrepreneurship hatch companies.

\section{Acknowledgment}

Fund Project: Hubei provincial committee of the communist youth league research office tracking research project "Research on the System of entrepreneurship education of young students " (2014GZ005) research results; Hubei Provincial Department of Education Humanities and Social Sciences special research project "college education and practice of social entrepreneurship -the perspective of innovating students' ideological education dimensions " (13z013) research results; Wuhan University of Technology exquisite course construction project" College students' entrepreneurship education and practice"(2014-IB-029) research results.

\section{References}

[1]Tang yayang. Outline of social entrepreneurship[M]. Chang sha: Hunan University Press 2009:3 [2] Hu youzhen. Have a restricted view on the disadvantages of undergraduate education from 
graduate students present situation [ J ]. China Higher Education Research, 2007(7):71-73.

[3]Tang yayang.Colleges and universities entrepreneurship education: concepts, practical significance and system building[J].University Education Science，2011（5): 49-53

[4]N.A.Kaiipob: "Pedagogy" part ii, People's Education Press, 1952. Pp. 290-289 